\title{
Sağlık Harcamaları ve Evrensel Kapsama Açısından Türk ve Alman Sağlık Sistemlerinin Karşılaştırmalı İncelenmesi'
}

Selin ERTÜRK ATABEY, Department of Public Finance, Faculty of Economics and Administrative Sciences, Gazi University, Turkey; e-mail: selinerturk@gazi.edu.tr

Metin MERIÇ, Department of Public Finance, Faculty of Economics and Administrative Sciences, Gazi

University, Turkey; e-mail: metinmeric@gazi.edu.tr

\section{A Comparative Study of Turkish and German Health Systems According to the Health Expenditure and Universal Coverage ${ }^{2}$}

\begin{abstract}
In this study, as in the Turkish health system it should be compared with the German health care system according to health expenditure and universal coverage. Both countries which are the greatest common denominator having a health systems to cover the entire population. Although another common based health care financing are conducted through the public economy in both countries. In this study, primarily in the prototype categorized which is stated that the health systems where are the Germany and Turkey. The comparison of two health systems in question are the method of in this study that in light of data earned from OECD, WB, WHO and TSI.
\end{abstract}

Keywords

Health Systems, Health Expenditure, Universal Coverage, Turkey, Germany.

JEL Classification Codes : $\quad$ H51, H55, G28.

$\ddot{\mathbf{O} z}$

Bu çalışmada Türk sağlık sistemi ile Alman sağlık sistemi sağlık harcamaları ve evrensel kapsama açısından karşılaştırılmalı olarak incelenmiştir. İki ülkenin en büyük ortak paydası tüm toplumu kapsamaya yönelik bir sağlık sistemine sahip olmalarıdır. Bir diğer ortak payda ise iki ülkede de sağlık hizmetinin finansmanı kamu ekonomisi aracılığıyla yürütülmektedir. Çalışmada öncelikle sağlık sistemlerinin ilk örnek kategorize ediliş biçimleri içinde Almanya ve Türkiye'nin

I Bu makale Sosyoekonomi Derneği ile Hacettepe Üniversitesi Piyasa Ekonomisini ve Girişimciliği Geliştirme Merkezi tarafindan Almanya'nın Münih şehrinde, 29-30 Ekim 2015 tarihlerinde düzenlenen "Birinci Uluslararası Sosyoekonomi Derneği Yıllık Buluşması"nda sunulan çalışmanın gözden geçirilmiş ve genişletilmiş halidir.

2 This article is the revised and extended version of the paper presented in "First International Annual Meeting of Sosyoekonomi Society" which was held by Sosyoekonomi Society and CMEE - Center for Market Economics and Entrepreneurship of Hacettepe University, in Munich/Germany, on October 29-30, 2015. 
hangi sistemde yer aldığı ifade edilmiştir. OECD, Dünya Bankası, Dünya Sağlık Örgütü ve TÜİK'den elde edilen veriler ışığında söz konusu iki sağlık sisteminin karşılaştırması çalışmanın yöntemidir.

Anahtar Sözcükler $\quad$ : Sağlık Sistemleri, Sağlık Harcaması, Evrensel Kapsama, Türkiye, Almanya.

\section{Giriş}

Kamu sektörü, özel sektör ve sivil toplum kuruluşları sağlık hizmetlerinin sunumundaki ana aktörlerdir. İkinci Dünya Savaşından sonra Birleşmiş Milletler Evrensel Bildirgesi’nde sağlık doğuştan kazanılmış bir hak olarak tanımlanmaktadır.

224 Sayılı Sağlık Hizmetlerinin Sosyalleştirilmesi Hakkında Kanun'un ${ }^{3}$ ikinci maddesinde "Sağlık hizmetleri, insan sağlı̆̆ına zarar veren çeşitli faktörlerin yok edilmesi ve toplumun bu faktörlerin tesirinden korunmast, hastaların tedavi edilmesi, bedeni ve ruhi kabiliyet ve melekeleri azalmış olanların işe alıştırılması (rehabilitasyon) için yapılan tıbbi faaliyetlerdir" denilmektedir.

Sağlık hizmetleri üç temel başlık altında sınıflandırılmaktadır. Bunlar; koruyucu sağlık hizmetleri, tedavi edici sağlık hizmetleri ve rehabilite edici sağlık hizmetleridir. Sağlık hizmetleri yarı kamusal hizmet olarak tanımlanmaktadır. Bu tür hizmetler tüketen kişiye bireysel fayda sağlamakla beraber tüketimleri sonucunda da topluma dişsal fayda da sağlamaktadır. Tüm sağlık hizmetleri ortak özellikler göstermemektedir. Koruyucu sağlık hizmetleri (aile planlaması, bulaşıcı hastalıklara karşı aşılama vb.) kamu ekonomisinde tam kamusal hizmet olarak kabul edilirken rehabilite edici ve tedavi edici sağlık hizmetleri ise yarı kamusal hizmet olarak kabul edilmektedir. Koruyucu sağlık hizmetlerinin tam kamusal sağlık hizmeti kabul edilmesindeki en önemli unsular bu hizmetler tüm topluma sunulmakta, bedelini ödemeyen faydasından mahrum birakılamamakta, fiyatlandırılamamakta ve pazarlanamamaktadır. Ayrıca, dışsallıkları, sağlık hizmetine global kamusal hizmet niteliği de kazandırmaktadır.

Çalışmada öncelikli olarak sağlık hizmeti kavramına değinilmiş ve sağlık hizmetinin kamu ekonomisindeki yeri açıklanmıştır. Daha sonra Evrensel Kapsama ve sağlık hizmetinin finansmanı için kullanılan ilk örnek finansman sistemlerinden bahsedilmiştir. Bu çalışmada Türk sağlık sistemi ile Alman sağlık sistemi evrensel kapsama ve sağlık hizmetlerinin finansmanı açısında karşılaştırılmalı olarak incelenmektedir. 
Ertürk Atabey, Selin \& M. Meriç (2016), "Sağlık Harcamaları ve Evrensel Kapsama Açısından Türk ve Alman Sağlık Sistemlerinin Karşılaştırmalı İncelenmesi”, Sosyoekonomi, Vol. 24(29), 113-131.

\section{Sağlık Hizmetleri Kavramı, Sağlık Hizmetlerinin Kamu Ekonomisindeki Yeri ve Sağlık Hizmetinin Finansman Sistemleri}

Kamu sektörü tarafindan sunumunun gerekçeleri, sağlık hizmetlerinin kamusallığı, erdemli mal olması, dışsallığı, tüketiminde talebin belirsiz olması, doğal tekel olması, tüketiminde asimetrik enformasyonun varlı̆̆1, sağlık hizmetlerine yönelik yapılan harcamaların beşeri sermayenin güçlenmesine olan katkısı ve sağlık hizmetlerinin adaletli dağıtılmasıdır.

Toplumsal koruyucu sağlık hizmetlerinin devlet tarafindan sunulmasının en önemli nedeni bu hizmetleri sunmaktan özel sektörün kaçınmasıdır. Bu kaçınmanın nedeni ise bu alanlarda faaliyet yapması özel sektör açısından karlı olmayacağı içindir. Örneğin; yüksek maliyetli hastaları kamu sektörüne bırakabilmektedir. Bazen toplumsal koruyucu sağlık hizmetleri özel sektör tarafından da sunulmaktadır. Ancak bu hizmetin kamusallık özelliğini değiştirmemektedir (Altay, 2008: 35-36).

Şüphesiz ki sağlık sektöründe özel sektör faaliyetlerinin önemi de oldukça fazladır. Kamu sektörü ile birlikte çalışan özel sektörün faydaları değerlendirilirken özel sektörün toplam performans üzerindeki etkileri göz önüne alınmaktadır. Sisteme yeni kaynaklar ve kapasite ilave edilmesi kamu servislerinin yoksul kesimlere odaklanmasına yardımcı olabilmektedir ya da özel sektör kıt kaynakları massedebilmektedir (Normand \& Thomas, 2008: 162).

Sağlık hizmetlerinin bu kadar tartışılır bir noktada yer almasının en önemli nedeni, sağlıklı bir hayat sürmenin yaşam hakkı ile doğrudan ilgisinin olmasıdır. (Süzek, 1985: 20-21) Bu açıdan değerlendirilerek sağlık, sosyal güvenlik araçları ile güvence altına alınmaktadır.

Sağlık finansman sistemleri ikiye ayrılmaktadır. Bunlardan ilki sağlık hizmetlerinin kamu ekonomisi aracılığıyla finansmanı diğeri ise sağlık hizmetlerinin piyasa ekonomisi tarafından finansmanıdır. Sağlık hizmetlerinin kamu ekonomisi aracılığıyla finansmanında iki yöntem yer almaktadır. Bunlar; Zorunlu / Yasal Sosyal Sigorta Yöntemi ile Finansman (Bismarck Modeli) ve Genel Vergilerle Finansman (Beveridge Modeli)'dır. Zorunlu Sosyal Sigorta Modeli ile devlet oluşturacağı sosyal sigorta ağı ile sağlık hizmetinin finansmanına müdahale edebilmektedir. Kamu tarafindan kurulan sigortalara bireyler belirli bir prim adı verilen aylık ödemeler yaparak finansmanın belirli bir kısmını üstlenmektedirler. Genel Vergilerle Finansman Modelinde sağlık hizmetlerinin tüm giderlerinin kamu bütçesinden karşılanması ve sağlık hizmetlerinde kullanılacak kaynakların vatandaşlardan genel vergiler yoluyla toplanması esastır. Sağlık hizmetlerinin piyasa ekonomisi aracılığıyla finansmanında da iki yöntem yer almaktadır. Bunlar; hizmet sırasında bedel ödeme yöntemi (cepten ödeme) ve özel sigorta yöntemi ile finansmandır. Cepten ödeme yöntemi aynı zamanda doğrudan finansman yöntemi olarak da bilinmektedir. Bu yöntemde sağllk hizmeti talebinde bulunan birey bunun bedelini doğrudan kendi cebinden ödemektedir. Özel sigorta yöntemi ile finansmanda ise sağlık 
hizmetlerinin finansmanı tamamen kar amacı güden özel sigorta şirketleri tarafından sağlanmaktadır. $\mathrm{Bu}$ yöntemde kişiler gelirlerine ve isteklerine göre çeşitli özel sağlık sigortalarına aylık peşin ödemelerde bulunmaktadırlar. (Atabey Ertürk, 2012: 31-35).

\section{Evrensel Kapsama ve Sağlık Harcamalarının Genel Görünümü}

Evrensel kapsama, tüm insanların yeterli kalitede ihtiyaç duydukları koruyucu, tedavi edici, rehabilite edici ve geçici sağlık hizmetlerinden faydalanabilmesi ve aynı zamanda bu hizmetlerin kullanımı esnasında kullanıcıya mali zorluk oluşturmaması olarak tanımlanmaktadır (WHO, 2015).

\section{Tablo: 1}

\section{Sağlık Finansman Sistemi ve Evrensel Kapsama}

\begin{tabular}{|c|c|c|c|c|c|}
\hline & \multicolumn{3}{|c|}{ Sağlık Sistemi ve Kamu/ Özel Sigorta Rolü } & \multicolumn{2}{|c|}{ Fayda Tasarımı } \\
\hline & $\begin{array}{c}\text { Hükümet } \\
\text { Rolü }\end{array}$ & $\begin{array}{c}\text { Kamu } \\
\text { Finansman } \\
\text { Sistemi } \\
\end{array}$ & $\begin{array}{c}\text { Özel } \\
\text { Sigortanın } \\
\text { Rolü } \\
\end{array}$ & $\begin{array}{c}\text { Maliyet } \\
\text { Paylaşımı }\end{array}$ & $\begin{array}{c}\text { Muafiyet ve Düşük } \\
\text { Gelirlilerin } \\
\text { Korunması }\end{array}$ \\
\hline Almanya & $\begin{array}{l}131 \text { rakip YSS } \\
\text { sigorta şirketi } \\
\text { (hastalı fonları) } \\
\text { (Yüksek gelirliler } \\
\text { kapsama dışında } \\
\text { kalmayı tercih } \\
\text { edebilirler) }\end{array}$ & $\begin{array}{l}\text { İşçi/işveren } \\
\text { payları } \\
\text { Genel vergi } \\
\text { gelirleri }\end{array}$ & $\begin{array}{l}\text { Nüfusun \%11'i YSS'den } \\
\text { vazgeçebilir ve YSS'ye ek } \\
\text { olarak ikame kapsamayı } \\
\text { satılırlar. } \\
\text { Bazı tamamlayıcı (yasal } \\
\text { küçük kar sağlayan } \\
\text { istisnalar) ve ek kapsama } \\
\text { (iyileştirilmiş olanaklar) }\end{array}$ & $\begin{array}{l}\text { Evet } \\
\text { Hane } \\
\text { gelirinin } \\
\% 2 \text { 'si } \\
\text { ve } \\
\text { Kronik } \\
\text { hastalıklar } \\
\text { için gelirin } \\
\% 1 \text { 'i } \\
\end{array}$ & $\begin{array}{l}\text { Çocuklar ve } 18 \\
\text { yaşından küçük } \\
\text { ergenler muaftır }\end{array}$ \\
\hline Türkiye* & \begin{tabular}{|l} 
GSS nüfusun \\
$\% 92,4$ '̈ kapsama \\
alanındadır. \\
(\%21,9 Yeşil Kart) \\
(\%72,3 SGK) \\
\end{tabular} & $\begin{array}{l}\text { İşçi/işveren } \\
\text { payları } \\
\text { Genel vergi } \\
\text { gelirleri }\end{array}$ & $\begin{array}{l}\text { Zorunluluk } \\
\text { bulunmaktadır. } \\
\text { Bireyler, isteğe ve gelir } \\
\text { seviyesine bağlı olarak } \\
\text { satın alabilirler. } \\
\end{array}$ & Evet & $\begin{array}{l}\text { Çocuklar ve } 18 \\
\text { yaşından küçük } \\
\text { ergenler (erkekler) } \\
25 \text { yaşından küçük } \\
\text { kızlar }\end{array}$ \\
\hline
\end{tabular}

Kaynak: International Profiles of Health Care Systems 2014, 2015: 6; TÜIK, SB verileri.

Tablo 1 incelendiğinde Almanya nüfusunun \%89’u yasal kapsama alanındadır. Alman sağlık sisteminde 131 rakip YSS şirketi ile hükümet sistemde yer almaktadır. Kamu finansmanı işçi/işveren payları ve geliri olmayan ve belirli bir sınırın altında bulunan kişilerin bakımında ise genel vergi gelirleri ile sağlamaktadır. Alman nüfusunun \%11'i YSS'den vazgeçerek özel sigorta satın alabilecek gelir düzeyine sahiptirler. Çocuklar ve 18 yaşından küçük ergenler muafiyet kapsamındadır. Türkiye'de ise nüfusun \%92,4'ü yasal kapsama alanındadır. Kamu finansmanı işçi ve işveren payları ve genel vergi gelirleri ile 
sağlanmaktadır. Özel sigortada yaptırmak isteğe bağlıdır. Çocuklar, 18 yaşından küçük erkekler ve 25 yaşından küçük evlenmemiş kızlar muafiyet kapsamındadır.

\section{Grafik: 1}

\section{DSÖ Avrupa Bölgesindeki Toplam Sağlık Harcamalarının GSYİH'deki Payı}

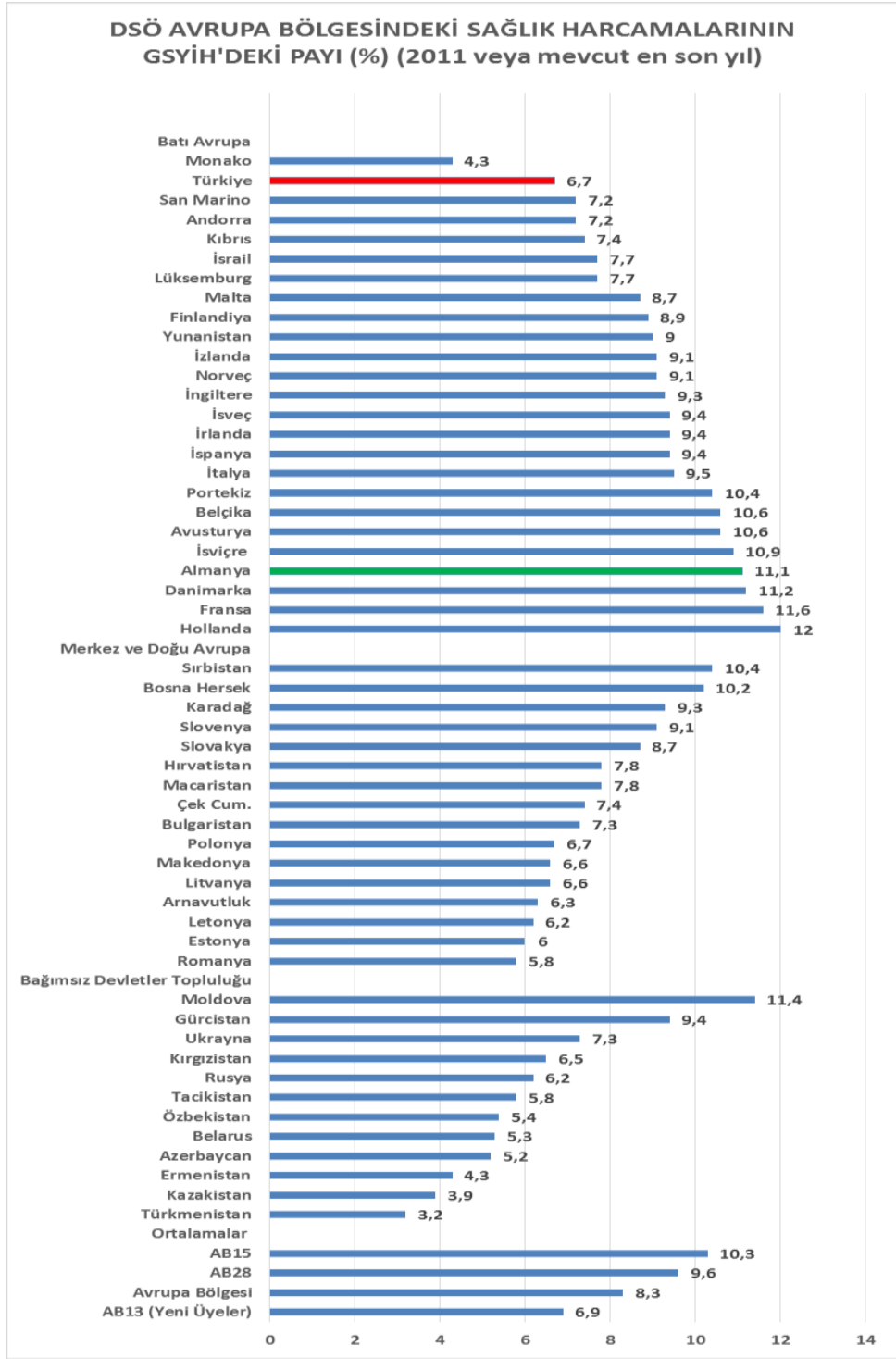

Kaynak: WHO Regional Office for Europe, 2015: 109. 
Grafik 1'de yer alan Dünya Sağlık Örgütü'nün (WHO) Avrupa Bölgesindeki sağlık harcamalarının GSYİH'deki payı incelendiğinde 53 ülke arasında Almanya \%11,1 oranı ile beşinci sırada yer alırken Türkiye \%6,7 oranı ile otuz altıncı sırada yer almaktadır. En son yapılan nüfus sayımlarına göre Almanya'da nüfus 80.296.685 iken Türkiye'de 78.523.053'tür. Birbirlerine bu kadar yakın iki nüfusun sağlık harcamalarına ayırdıkları paylar birbirlerinden ciddi ölçüde farklıdır. Bunun en önemli sebebi ise iki ülke arasında sağlığa yönelik algı farkıdır. Yasal düzenlemelerde Almanya'da sağlığa bir hak olarak bakılırken Türkiye'de ise yükümlülük olarak bakılmaktadır. Bunun en önemli nedeni ise sağlıkla ilgili modern devlet anlayışına Almanya'da Türkiye'den daha önce geçilmiş olmasidir.

Grafik: 2

\section{OECD Ülkelerinde Toplam Sağlık Harcamalarının GSYİH İçindeki Payı (\%) (2012)}

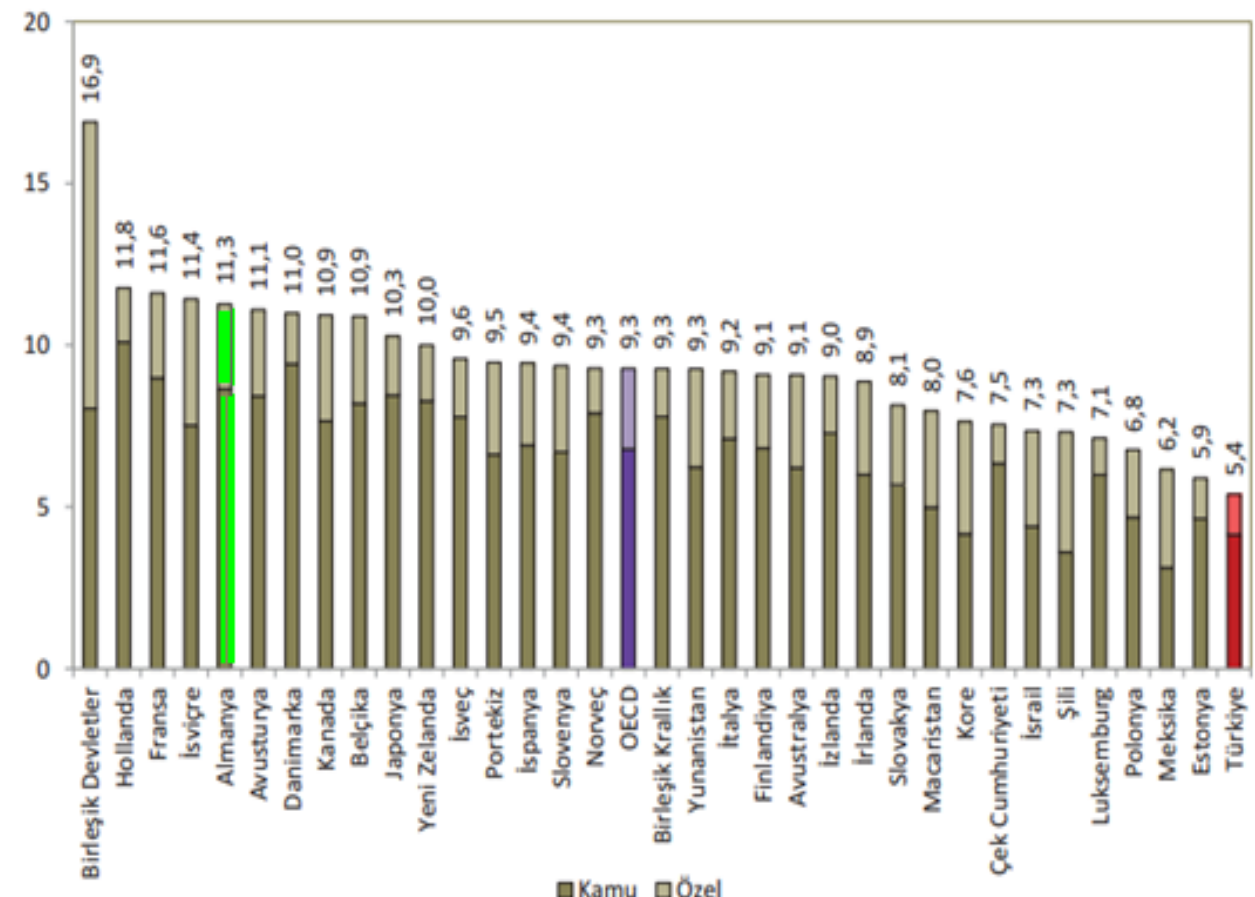

Kaynak: Sağllk Bakanlı̆̆, 2013.

Grafik 2 incelendiğinde Türkiye OECD ortalamasının 3,9 puan gerisinde olarak 34 ülke arasında en son sirada yer almaktadır. Almanya ise OECD ortalamasının 2 puan üzerinde yer alarak 34 OECD ülkesi arasında beşinci sırada yer almaktadır. 
Ertürk Atabey, Selin \& M. Meriç (2016), "Sağlık Harcamaları ve Evrensel Kapsama Açısından Türk ve Alman Sağlık Sistemlerinin Karşılaştırmalı İncelenmesi”, Sosyoekonomi, Vol. 24(29), 113-131.

\section{Grafik: 3 \\ DSÖ Avrupa Bölgesindeki Kamu Sağlık Harcamalarının Toplam Sağlık Harcamaları İçindeki Payı}

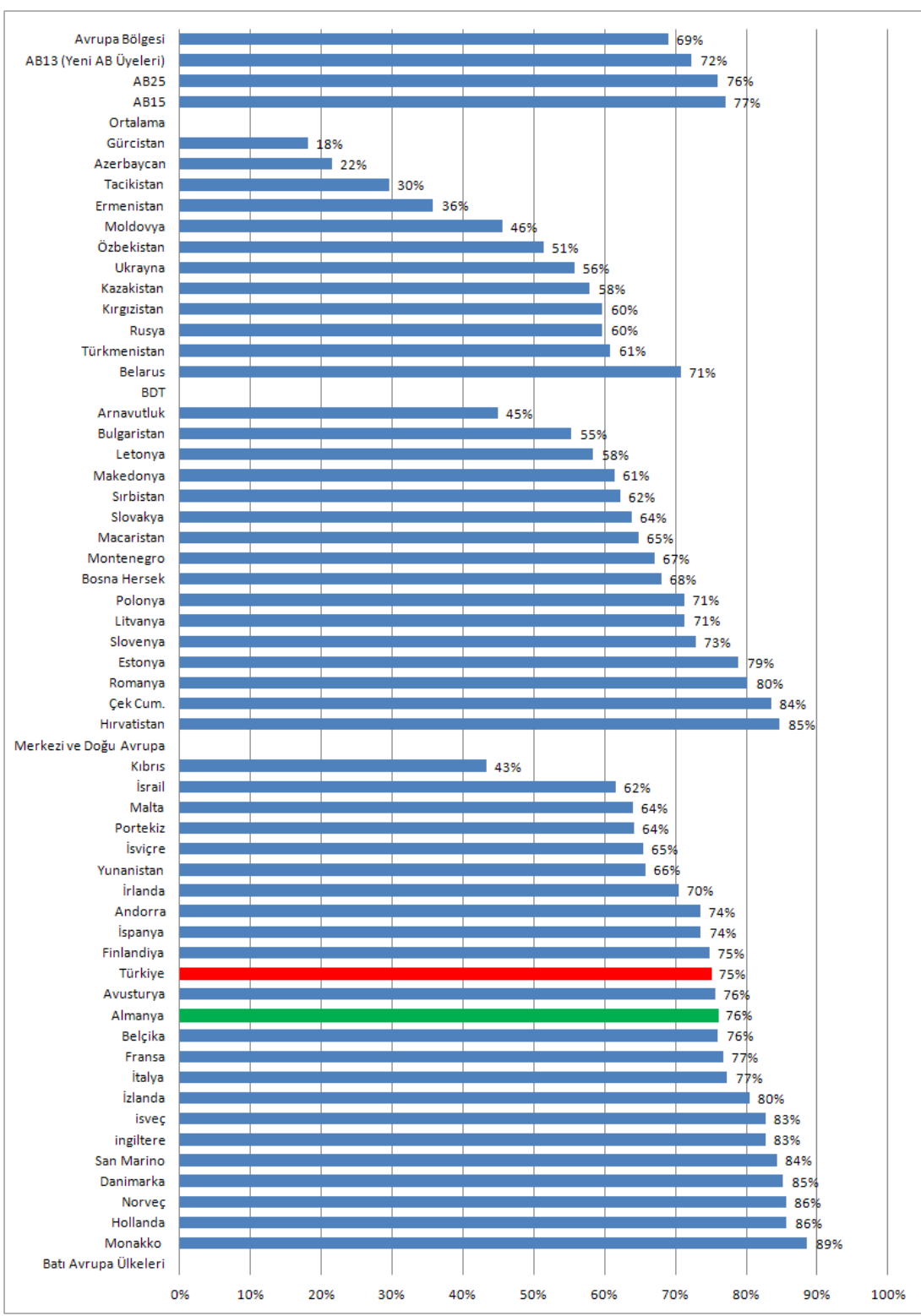

Kaynak: WHO Regional Office for Europe, 2015: 112. 
Grafik 3 incelendiğinde 52 Avrupa ülkesi arasında kamu sağlık harcamalarının toplam sağlık harcamalarındaki payı açısından Almanya \%76 oranı ile on sekizinci ülke olurken Türkiye $\% 75$ oranı ile 19 ülke durumundadır. İki ülkede de kamu kaynaklı sağlık harcamaları son 15 yılda azılmıştır. Bunun en önemli sebebi ise özel harcamalardaki artış ve vergi ile finanse edilen hizmetlerin yüzdesindeki azalmadır.

Grafik: 4

OECD Ülkelerinde Kişi Başı Toplam Sağlık Harcaması (Kamu ve Özel) SGP (ABD \$) (2012)

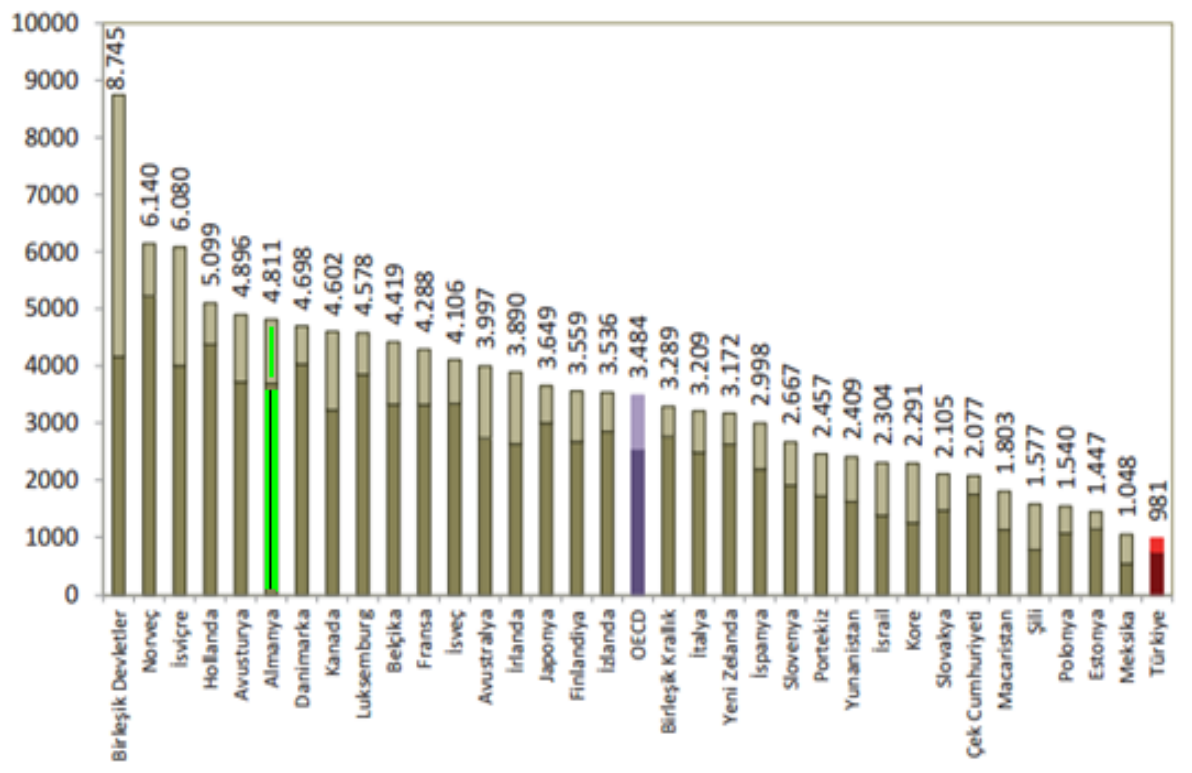

Kaynak: Sağllk Bakanlı̆̆, 2013.

Grafik 4 incelendiğinde ise OECD ülkelerinde kişi başı toplam sağlık harcaması açısından 34 ülke arasında Almanya altıncı sırada yer alırken Türkiye ise yine en son sırada yer almaktadır. OECD ülkeleri arasında en son sırada Türkiye'nin en son sırada yer almasındaki en önemli etken kişi başına düşen gelirin söz konusu ülkeler arasında en az olanı olmasındandır. 
Ertürk Atabey, Selin \& M. Meriç (2016), "Sağlık Harcamaları ve Evrensel Kapsama Açısından Türk ve Alman Sağlık Sistemlerinin Karşılaștırmalı İncelenmesi”, Sosyoekonomi, Vol. 24(29), 113-131.

\section{Alman Sağlık Sistemi: Zorunlu/Yasal Sağlık Sigorta (SHI) Yöntemi (Bismarck Modeli)}

Almanya, sağlık sigortasına yönelik yasanın 1884'te yürürlüğe girmesi ile beraber Yasal Sağlık Sigortası (YSS) uygulamasını başlatmıştır. YSS'yi kaza, yaşlılık ve iş görmezlik sigortaları izlemiş ve Bismarck'ın sosyal yasaları ile bu yüzyıl son bulmuştur. YSS'nin kapsamı, hastalığa bağlı iş görememe durumu, doktor tedavisi ve ölüm parasından oluşmaktadır. 1970'li yıllarda YSS kapsamındaki nüfus oranı \%90'lara ulaşmıştır. (Öcek, 2007: 84) Yıllar itibariyle sağlıkta reformlar özellikle maliyet kısıtlamaları yapmak üzere şekillenmiş ve bu doğrultuda maliyet azaltma kanunları çıkarılmıştır. 1990'lardan sonra ise hükümetler YSS kapsamının daraltılması, cepten ödemelerin getirilmesi, YSS'de özel sigorta mantığının geliştirilmesi şeklinde maliyet azaltıcı politikalar oluşturulmuşlardır. 1996-1997 yıllarında cepten ödemeleri artırıcı kanunlar çıkarılarak koruyucu ve rehabilite edici sağlık hizmetleri sınırlandırılmıştır.

Almanya, sağlık harcamalarına ülke zenginliğinin önemli bir miktarını ayırmaktadır. Alman Federal İstatistik verilerine göre, toplam sağlık harcaması 2012 yılında 300,4 milyon €'dur. Bu tutar GSYİH'nin \%11,4 oranına karşılık gelmektedir. OECD verilerine göre, 2000-2009 yılları arasında kişi başına düşen sağlık harcamalarında reel büyüme yıllık ortalama $\% 2,1$ ' iken OECD ülkeleri arasında yıllık \%4,1 oranında büyümektedir. Bu verileri yorumlarken dikkat edilmesi gereken Slovakya $(\% 10,9)$, Kore $(\% 9,3)$ gibi sağlık harcamalarındaki büyümenin nispeten yüksek oranlara sahip olduğu bazı ülkelerde 1990'larda çok düşük harcamalar yapılmaktaydı. Buna karşılık, Almanya ve Fransa gibi ülkelerde harcamaların zaten yüksek olduğu ve o dönemin son yıllarında çeşitli maliyet kontrol önlemlerinin alındığı unutulmamalıdır. Sağlık harcamalarındaki büyümelerin nispeten yüksek oranlarda olduğu Slovakya $(\% 10,9)$, Kore $(\% 9,3)$ gibi ülkelerde 1990'larda çok düşük harcamalar bulunmaktaydı bu yüzden son yıllarda ciddi oran artışları olduğu ve bunun bir iyileşme hali olduğu yanılgısı ortaya çıkmaktadır. Buna karşılık, Almanya ve Fransa gibi ülkelerde harcamalar zaten oldukça yüksek olduğu için maliyet kontrol önemlerine tabi olduğu için bu ülkelerde ise bir kötüleşme yanılgısı ortaya çıkmaktadır (Busse \& Blümel, 2014: 107).

Almanya'da Yasal Sağlık Sigortaları ile beraber 2009 yılından bu tarafa RSA olarak adlandırılan sigorta uyuşmazlıklarına çözüm sunan sigorta şirketi federal ve eyalet hükümetleri sağlık finansmanında söz sahibidirler. 1996 yılından beri hastane finansmanında ise hastane ödemeleri sabit bütçe üzerinden gerçekleştirilmektedir. Sağlık yatırımları eyaletlerce karşılanırken, sağlık cari harcamaları ise, hastalık fonları ve hastaların cepten ödemelerince karşılanmaktadır.

Şedül 1 incelendiğinde Almanya'da sağlı̆̆ın payı isteğe bağlı özel sigorta primlerinde $(\% 9,3)$, genel vergilerde $(\% 1,8)$, katk1 paylarında $(\% 7,7)$, ekstra ödemelerde ise $(\% 4,8)$ 'dir. 
Şedül: 1

Alman Sağlık Finansman Sisteminin İşleyişi

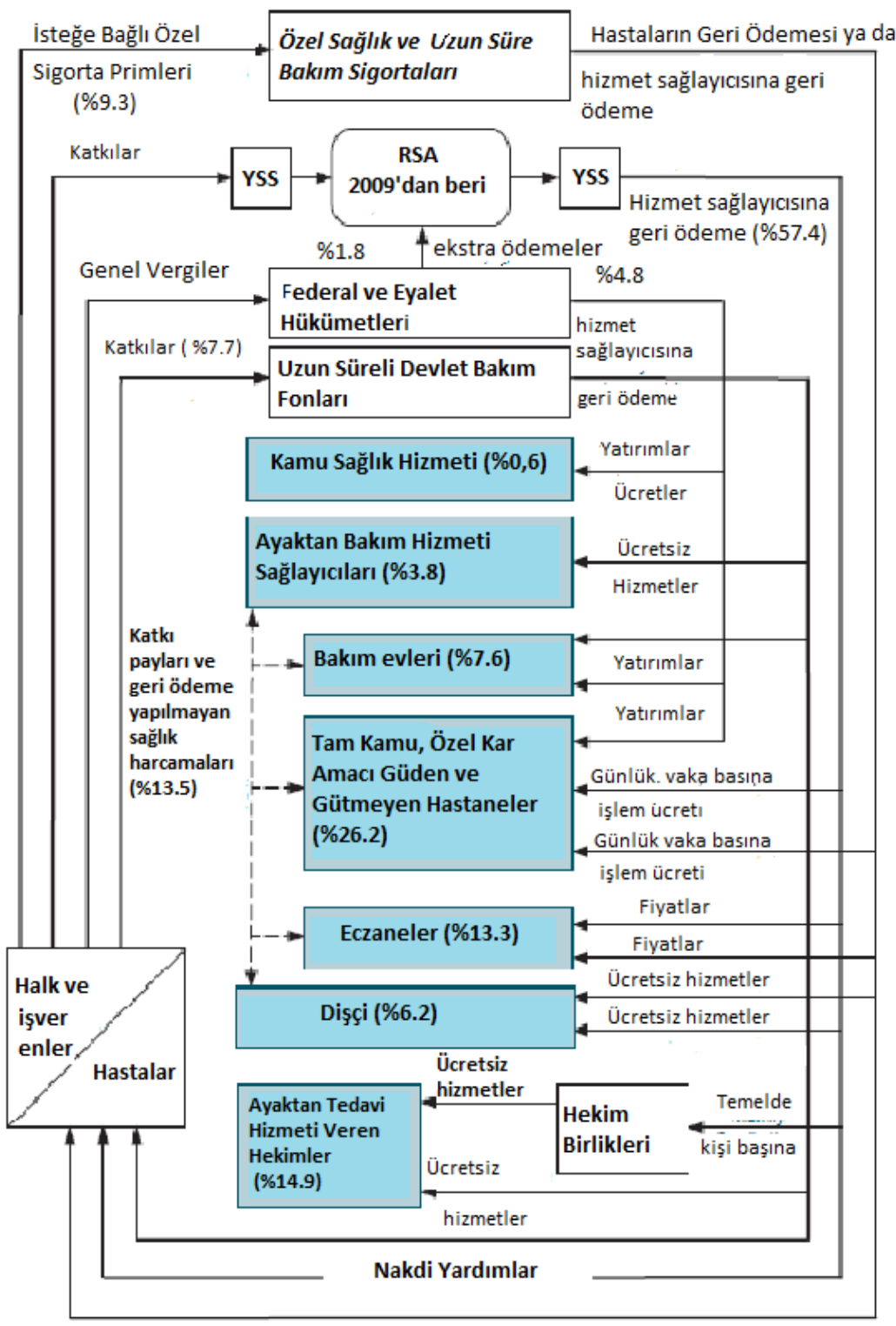


Ertürk Atabey, Selin \& M. Meriç (2016), "Sağlık Harcamaları ve Evrensel Kapsama Açısından Türk ve Alman Sağlık Sistemlerinin Karşılaştırmalı İncelenmesi”, Sosyoekonomi, Vol. 24(29), 113-131.

Tablo: 2

Almanya'da Sağlık Harcamalarının Seyri (1995-2011)

\begin{tabular}{|c|c|c|c|c|c|c|c|c|c|}
\hline & 1995 & 2000 & 2005 & 2006 & 2007 & 2008 & 2009 & 2010 & 2011 \\
\hline \multicolumn{10}{|c|}{ Toplam Sağlık Harcaması } \\
\hline Cari Fiyat (Milyar $€$ ) & 186.9 & 212.8 & 240.4 & 246.0 & 254.2 & 264.4 & 278.4 & 287.3 & 293.8 \\
\hline Kişi Başına Cari Fiyat (ABD \$) & 2.276 & 2.678 & 3.362 & 3.567 & 3.722 & 3.967 & 4.225 & 4.338 & 4.495 \\
\hline GSYİH'deki Payı (\%) & 10.1 & 10.4 & 10.8 & 10.6 & 10.5 & 10.7 & 11.7 & 11.6 & 11.3 \\
\hline \multicolumn{10}{|c|}{ Kamu Sağlık Harcaması } \\
\hline Toplam Harcamalarda Sağlığın Payı (\%) & 81.4 & 79.5 & 76.6 & 76.5 & 76.4 & 76.6 & 76.9 & 76.8 & 76.5 \\
\hline GSYÍH'deki Payı (\%) & 8.2 & 8.3 & 8.3 & 8.1 & 8.0 & 8.2 & 9.0 & 8.9 & 8.7 \\
\hline \multicolumn{10}{|c|}{ Özel Sağlık Harcaması } \\
\hline Toplam Harcamalarda Sağlığın Payı (\%) & 18.6 & 20.5 & 23.4 & 23.5 & 23.6 & 23.4 & 23.1 & 23.4 & 23.5 \\
\hline GSYİH'deki Payı (\%) & 1.8 & 2.1 & 2.5 & 2.5 & 2.5 & 2.5 & 2.7 & 2.7 & 2.7 \\
\hline \multicolumn{10}{|c|}{ Cepten Yapılan Ödemeler Dışında Sağlık Harcaması } \\
\hline Toplam Harcamalarda Sağlığın Payı (\%) & 10.0 & 11.4 & 13.5 & 13.7 & 13.6 & 13.3 & 13.0 & 13.2 & 12.4 \\
\hline \multirow[t]{2}{*}{ Özel Harcamalarda Sağlığın Payı (\%) } & 54 & 56 & 58 & 58 & 58 & 57 & 56 & 56 & 53 \\
\hline & \multicolumn{2}{|c|}{ 1995-2000 } & 2001-2005 & \multicolumn{5}{|c|}{ 2006-2010 } & 2009-2011 \\
\hline $\begin{array}{l}\text { Toplam Sağlık Harcamalarında Ortalama Yıllık Büyüme Oranı } \\
(\%)\end{array}$ & \multicolumn{2}{|c|}{2.3} & 1.4 & \multicolumn{5}{|c|}{2.7} & 2.8 \\
\hline GSYİH'deki Ortalama Yıllık Büyüme Oranı & \multicolumn{2}{|c|}{1.8} & 0.8 & \multicolumn{5}{|c|}{1.4} & 4.6 \\
\hline
\end{tabular}

Kaynak: OECD, 2013a; 2014b; Busse \& Blümel, 2014: 108.

Almanya'da toplam sağlık harcamalarının GSYİH içindeki payının \%10’lar civarında seyrettiği görülmektedir. 2001 yılı verisine göre bu oran \%11,1'dir. Bu durum da Almanya'da sağlığa verilen değerin bir göstergesi olmaktadır. Toplam sağlık harcamaları içerisinde kamu sağlık harcamalarının 1995 yılında \%81,4; 2006 yılında \%76,5; 2009 yılında \%76,9; 2010 yılında \%76,8 ve 2011 yılında ise \%75,9 oranında çok az bir azalmayla kamunun sağlıktaki payının ağırlıkta olduğu görülmektedir. Almanya gerçekleştirdiği tüm sağlık harcamalarını kendi kaynakları ile finanse ettiğinden toplam sağlık harcamalarında dış kaynakların payı bulunmamaktadır. Toplam sağlık harcamaları içerisinde özel sağlık harcamalarının payı 1995 ile 2011 yılları arasında \%18,6 ile \%23,5 dolaylarında seyrettiği görülmektedir. Bu noktada, sağlık hizmetlerinin finansmanında özel sektöre göre Almanya'da kamunun daha etkili rol oynadığını söylemek yanlış olmayacaktır (WHO, 2015).

Almanya'da sağlık sisteminin finansmanının yasal sağlı sigortası ile yapıldığının en net göstergesi verilerdir. Bu veriler ışı̆̆ında 1995 yılında sağlığa ilişkin sosyal güvenlik harcamalarının kamu sağlık harcamaları içerisindeki payı \%82,5; 1996 yılında $\% 84,3 ; 1997$ yıllnda $\% 86,5 ; 1998$ y1linda $\% 87 ; 1999$ ve 2000 yıllnda $\% 87,3 ; 2001$ y1lında $\% 87,2 ; 2002$ yilında $\% 87,3 ; 2003$ yılında $\% 90,2 ; 2004$ y1lında $\% 90 ; 2005$ yılında $\% 90,3 ; 2006$ yılında \%90,5; 2007 yilında \%90,7; 2008 ve 2009 yıllinda \%90,8; 2010 yılında \%91 ve 2011 yılında \%91,2 olarak gerçekleşmiştir. Almanya'da cepten yapılan sağlık harcamalarının özel sağlık harcamaları içersindeki payı görülmektedir. Bu oran 1995-2011 arasında \%52,5 ile \%55,9 arasında seyretmiştir. Almanya'da özel peşin planların özel sağlık harcaması içerisindeki yeri 1995 ve 2011 yılları arasında \%42 ile \%47 arasında seyretmektedir. Ortalama döviz kuru üzerinden kişi başına düşen sağlik harcaması kamu ve özel toplamı ABD Doları cinsinden 1995 yılında 3123 \$ olarak gerçekleşirken 2011 yılında 4371 \$' a yükselmiştir. Ortalama döviz kuru üzerinden kişi başına düşen kamu sağlık harcamaları 1995 yılında 2548 \$ iken 2011 yılında 3723 \$ olarak 
gerçekleşmiştir. Satın alma gücü paritesine göre kişi başına düşen kamu sağlık harcamaları 1995 yılında 1848 \$ iken 2011 yılında 3813 \$'a yükselmiştir (WHO, 2015).

Almanya'da kural olarak yaşayan tüm bireyler sağlık sisteminde evrensel kapsama ile kapsanmaktadır. Kapsam geneldir. Herkes sağlık sisteminden yasal sağlık sigortasına sahip olmak koşuluyla ayrım yapılmaksızın sağlık hizmetlerinden faydalanmaktadırlar. Ancak uygulamada nüfusun yaklaşık \%11'inin kapsam dışında kaldığı ve evrensel kapsamanın bu ülkede gerçekleşmediği görülmektedir.

Şekil: 1

\section{Toplam Sağlık Harcamalarında Finansmanın Ana Kaynakları}

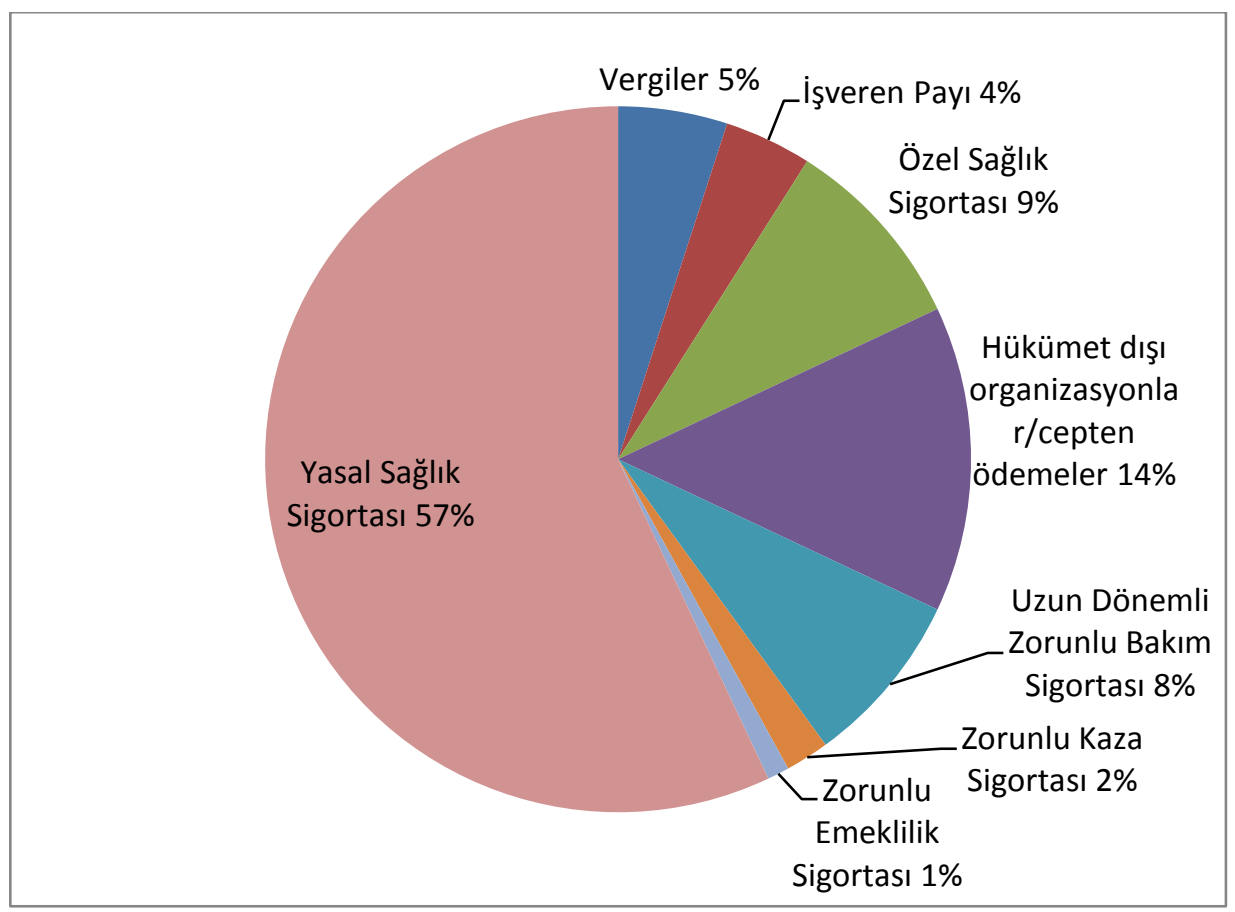

Kaynak: Busse \& Blümel, 2014: 117.

Toplam sağlık harcamalarında finansmanın ana kaynağı \%57 oranı ile Yasal Sağlık Sigortasıdır. Vergilerle finansman 1996 yılında \%10,8 iken 2012 yılında \%4,8'e düşmüştür. 
Şedül: 2

Türk Sağlık Finansman Sistemini İşleyişi

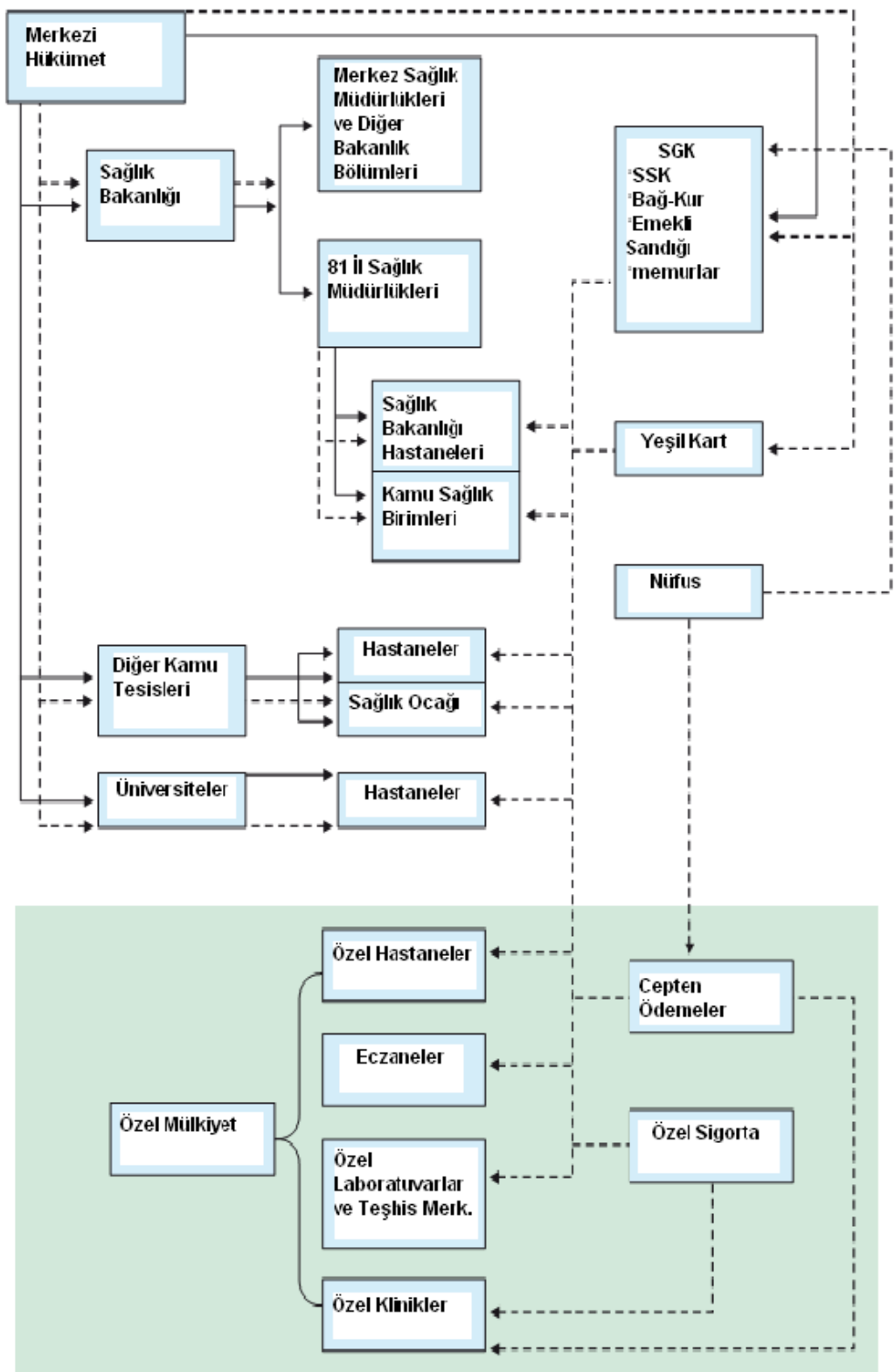

Kaynak: Tatar vd., 2011: 39. 
Tablo: 3

Sağlık Finansman Sisteminin Kaynakları

\begin{tabular}{|l|c|c|c|c|c|c|c|c|c|c|c|}
\hline Kaynaklar & $\mathbf{2 0 0 2}$ & $\mathbf{2 0 0 3}$ & $\mathbf{2 0 0 4}$ & $\mathbf{2 0 0 5}$ & $\mathbf{2 0 0 6}$ & $\mathbf{2 0 0 7}$ & $\mathbf{2 0 0 8}$ & $\mathbf{2 0 0 9}$ & $\mathbf{2 0 1 0}$ & $\mathbf{2 0 1 1}$ & $\mathbf{2 0 0 2}$ \\
\hline Kamu Kaynakları & 75,2 & 74,6 & 73,1 & 73,1 & 73,0 & 73,0 & 72,9 & 73,0 & 72,9 & 72,6 & 72,9 \\
\hline Vergiler & 7,8 & 7,8 & 6,0 & 5,7 & 5,5 & 5,2 & 5,0 & 4,9 & 4,8 & 4,8 & 4,8 \\
\hline Yasal Sağlık Sigortası & 56,9 & 56,7 & 56,3 & 56,8 & 57,0 & 57,5 & 57,5 & 57,8 & 57,6 & 57,3 & 57,4 \\
\hline Zorunlu Emeklilik Sigortası & 1,7 & 1,8 & 1,5 & 1,5 & 1,5 & 1,5 & 1,5 & 1,4 & 1,4 & 1,4 & 1,4 \\
\hline Zorunlu Kaza Sigortası & 1,7 & 1,7 & 1,7 & 1,7 & 1,7 & 1,6 & 1,6 & 1,6 & 1,6 & 1,6 & 1,6 \\
\hline $\begin{array}{l}\text { Uzun Dönemli Zorunlu } \\
\text { Bakım Sigortası }\end{array}$ & 7,0 & 6,9 & 7,5 & 7,5 & 7,4 & 7,3 & 7,3 & 7,3 & 7,5 & 7,5 & 7,7 \\
\hline Özel Kaynaklar & 24,7 & 25,4 & 26,9 & 26,9 & 27,0 & 27,0 & 27,1 & 27,0 & 27,1 & 24,7 & 27,1 \\
\hline $\begin{array}{l}\text { Cepten Ödemeler/ } \\
\text { Hükümetdışı Organizasyonlar }\end{array}$ & 12,2 & 12,3 & 13,6 & 13,5 & 13,6 & 13,5 & 13,4 & 13,5 & 13,6 & 13,7 & 13,5 \\
\hline Özel Sağlık Sigortası & 8,4 & 8,6 & 9,1 & 9,2 & 9,2 & 9,3 & 9,5 & 9,3 & 9,3 & 9,4 & 9,3 \\
\hline İssverenler & 4,1 & 4,1 & 4,2 & 4,2 & 4,2 & 4,2 & 4,2 & 4,2 & 4,2 & 4,3 & 4,3 \\
\hline
\end{tabular}

Kaynak: Busse \& Blümel, 2014: 116.

\section{Türk Sağlık Sistemi: Genel Sağlık Sigortası (GSS) Yöntemi}

Tüm dünyada olduğu gibi Türkiye'de de sağlık hizmeti özel kesim ve kamu kesimi olmak üzere iki sektör tarafından sunulmaktadır. Sağlık hizmetleri bir yandan kamu ve Sosyal Güvenlik Kurumu (SGK) tarafindan sunulurken kamu sektörünün farklı gruplardaki hizmet standartları birbirinin aynısı değildir.

Türkiye'de toplam sağlık harcamaları içerisinde kamu sağlık harcamalarının payı 1995 yılından günümüze kadar \%70’ler dolayında seyretmektedir. 1995 yılında \% 70,2; 2009 yılında ise \% 75,2 olarak gerçekleşmiştir. 1995 yılında 2009 yılına kadar en büyük düşüş 1999 yılında gerçeklemiş ve bu oran \%61,1 olarak veri kaynaklarına yansımıştır. Türkiye'de bu oran 2011 yılında \%76,3 olarak gerçekleşmiştir. (WHO, 2014).

Tablo: 4

Türkiye'de Toplam Sağlık Harcamalarının Seyri

\begin{tabular}{|l|c|c|c|c|c|c|c|c|c|c|c|}
\hline & $\mathbf{2 0 0 3}$ & $\mathbf{2 0 0 4}$ & $\mathbf{2 0 0 5}$ & $\mathbf{2 0 0 6}$ & $\mathbf{2 0 0 7}$ & $\mathbf{2 0 0 8}$ & $\mathbf{2 0 0 9}$ & $\mathbf{2 0 1 0}$ & $\mathbf{2 0 1 1}$ & $\mathbf{2 0 1 2}$ & $\mathbf{2 0 1 3}$ \\
\hline $\begin{array}{l}\text { Toplam } \\
\text { Sağlık } \\
\text { Harcaması } \\
\text { (Milyon TL) }\end{array}$ & 24.279 & 30.021 & 35.359 & 44.069 & 50.904 & 57.740 & 57.911 & 61.678 & 68.607 & 74.189 & 84.390 \\
\hline $\begin{array}{l}\text { Toplam } \\
\text { Sağlık } \\
\begin{array}{l}\text { Harcamasının } \\
\text { GSYïH'ye } \\
\text { Oranı (\%) }\end{array}\end{array}$ & 5,3 & 5,4 & 5,4 & 5,8 & 6,0 & 6,1 & 6,1 & 5,6 & 5,3 & 5,2 & 5,4 \\
\hline
\end{tabular}

Kaynak: WHO, 2015; TÜIK.

Toplam sağlık harcamaları içerisinde Türkiye dönem dönem dış kaynaklardan yardım almıştır. Ancak bu yardımın toplam sağlık harcamaları içerisindeki payı en fazla, 
1995 yılında \%1,5 olarak gerçekleşmiştir. 1996 yılında bu oran; \%0,1; 1997 yılında \%0,1; 1998 ve 1999 yilında \%0,0; 2000 yılında \%0,1; 2001 yılında \%0,3; 2002 yilında \%0,0; 2003 yılında \%0,2 ve 2004 ve sonrası yıllarda ise sıfır olarak gerçekleşmiştir. (WHO, 2014). Toplam sağlık harcamaları içerisinde özel sektör sağlık harcamalarının payı $\% 25$ 'lerin üzerinde seyretmektedir.

Sağlığa ilişkin sosyal güvenlik harcamalarının kamu sağlık harcamaları içerisindeki payı, 1999 yılında \%33,7 iken yaklaşık iki katı artarak 2009 yılında \%60,1'e ulaşmıştır. 1995 yılından 2009 yılına cepten yapılan sağlık harcamalarının özel sağlık harcamaları içerisindeki payı 35,3 puan düşmüş ve \%64,7 olarak gerçekleşmiştir. Bu durumda, cepten yapılan sağlık harcamaları yerine özel sigortalılığın artışının bir göstergesidir. Ortalama döviz kuru üzerinden kişi başına düşen sağlık harcamaları kamu ve özel toplamı 1995 yılında 84\$ iken 2009 yılında 571\$ olmuştur. Ortalama döviz kuru üzerinden kişi başına düşen kamu sağlık harcamaları 2009 yılında 429\$ olarak karşımıza çıkmaktadır. Satın alma gücü paritesine göre kişi başına düşen kamu sağlık harcamaları 2009 yılında 726\$ olarak gerçekleşmektedir 2011 yılında ise bu oran 901\$ olarak gerçekleşmiştir.

Grafik: 3

Kamu ve Özel Sağlık Harcamasının GSYİH'deki Payı (\%)

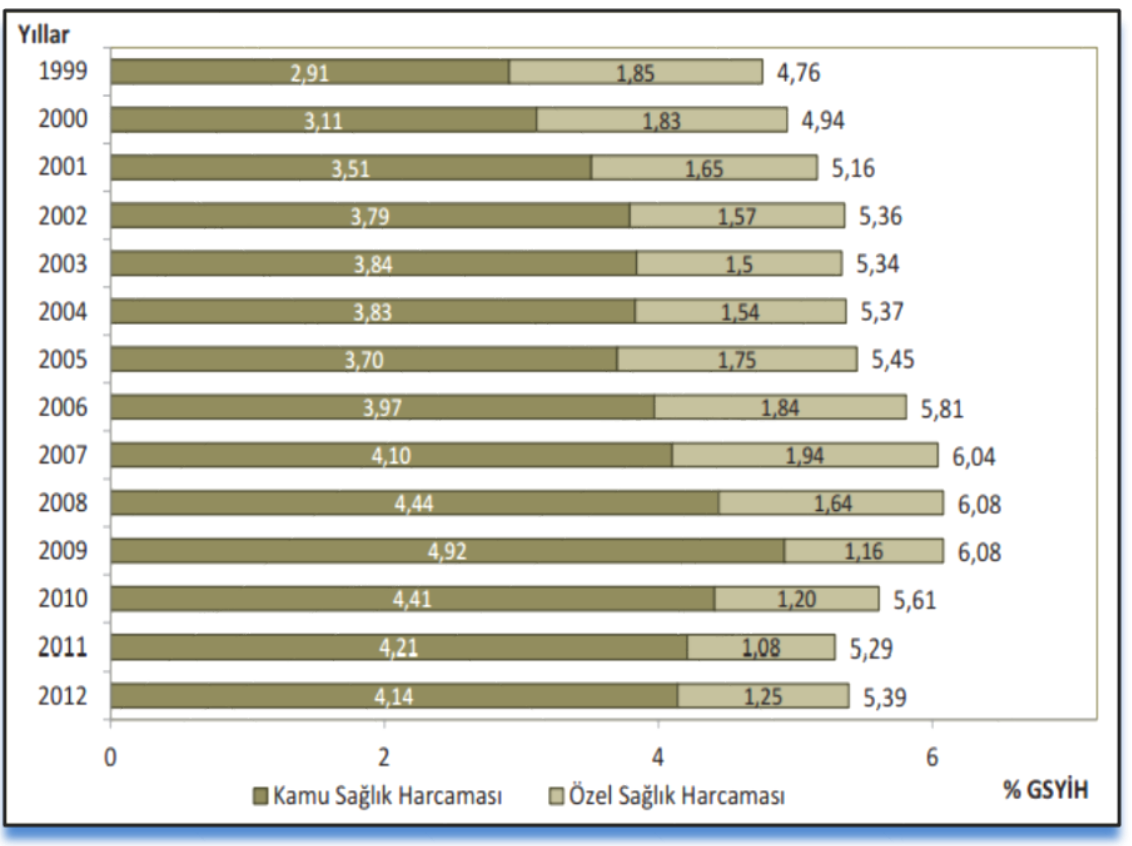

Kaynak: Să̆llk Bakanlı̆̆l, 2013. 
Grafik 3 incelendiğinde sağlık harcamalarının devlet ve özel sektör tarafindan sunumunda yapılan ayrım görülmektedir. Buna göre sağlık harcamalarının yaklaşık olarak dörtte üçü devlet tarafindan, dörtte biri ise özel sektör tarafindan yapılmakta olup devlet tarafindan sunulan sağlık hizmetlerinin büyük kısmı da merkezi yönetime aittir. Bu durum, sağlık hizmetlerinin sunumunda kamu sektörünün ne derece önemli olduğunu göstermektedir. Ancak, Türkiye'de son dönemlerde, kamusal sağlık hizmetlerinin etkin sunulamaması gibi nedenlerle özel sağlık harcamalarının da önemli oranda arttığı dikkat çekmektedir. Kamu sağlık harcama oranlarının artması sosyal güvenlik kurumlarının sağlık harcamalarındaki artış ile yeşil kart harcamalarındaki artış önemli etkendir. Sağlığa ilişkin sosyal güvenlik harcamalarının kamu sağlık harcamaları içindeki payı 1995 yılında \%33,7; 2000 yılında \%55,5 ve 2009 yılında \%60,1 olmuştur. Söz konusu bu oranın yıllar itibariyle artması aynı zamanda sağlık hizmetinin kalitesinin de arttığının salt bir göstergesi olarak kabul edilemez.

Yukarıdaki istatistikler 1şığında; tüm dünyada olduğu gibi Türkiye'de de özellikle son on beş yılda sağlık harcamalarının GSYİH'e oranı önemli ölçüde artmıştır. $\mathrm{Bu}$ artışlarda, kişi başına düşen gelirin artması, sağlık sigortası kapsamının genişlemesi, sağlık sisteminin kapsadığı nüfusun artması, nüfusun yaşlanması, teknolojik değişmeler ve sağlık sektörünün emek yoğun olması sebebiyle düşük verimlilik artışının yaşanması gibi faktörler etkili olmaktadır (Akdemir \& Karakurt, 2009: 21).

\section{Tablo: 5}

\section{Türkiye’de Sağlık Sigortası Kapsamı ve Prim Oranları}

\begin{tabular}{|c|c|c|c|c|}
\hline Nüfus Grubu & $\begin{array}{l}\text { Kapsama } \\
\text { Mekanizması }\end{array}$ & Katkı Kaynağı ve Oranı & $\begin{array}{l}\text { Zorunlu ya da Gönüllü } \\
\text { Üyelik }\end{array}$ & \begin{tabular}{|l|} 
Bakmakla \\
Yükümlüler İçin \\
Kapsama \\
\end{tabular} \\
\hline Özel Sektör Çalışanları & GSS & $\begin{array}{l}\text { Ücretin \%12,5'si } \\
\text { (\%7,5 işveren; \%5 işçi) }\end{array}$ & Zorunlu & Evet \\
\hline $\begin{array}{l}\text { Mavi Yakalı Kamu Sektör } \\
\text { Çalışanları }\end{array}$ & GSS & $\begin{array}{l}\text { Ücretin \%12'si } \\
\text { (\%7 işveren; \%5 işçi) }\end{array}$ & Zorunlu & Evet \\
\hline $\begin{array}{l}\text { Serbest Meslek Erbabı, Esnaf } \\
\text { ve Tüccarlar }\end{array}$ & GSS & Gelirin \%12'si & $\begin{array}{l}\text { Asgari ücretten daha fazla } \\
\text { geliri olanlar için zorunlu }\end{array}$ & Evet \\
\hline Tarım İşçileri & GSS & Gelirin \%12'si & $\begin{array}{l}\text { Asgari ücretten daha fazla } \\
\text { geliri olanlar için zorunlu }\end{array}$ & Evet \\
\hline Emekli İşçiler & GSS & $\begin{array}{l}\text { Aktif çalışırken ödedikleri primler } \\
\text { (Emekliyken prim kesintisi } \\
\text { yapılmıyor) }\end{array}$ & Zorunlu & Evet \\
\hline $\begin{array}{l}\text { Asgari Gelirin üçte birinden az } \\
\text { kişisel geliri olan vatandaşlar }\end{array}$ & Yeşil Kart & Merkezi Bütçe & $\begin{array}{l}\text { Hak etmek için bazı } \\
\text { araştırmalara tabiler }\end{array}$ & Hayır \\
\hline $\begin{array}{l}\text { İşsiz İnsanlar için İşsizlik } \\
\text { Sigortası }\end{array}$ & GSS & Merkezi Bütçe & Hak kazandıkları zaman & Hayır \\
\hline $\begin{array}{l}\text { Türkiye'de ikamet eden } \\
\text { yabancılar }\end{array}$ & GSS & Gelirin \%12'si & Gönüllü & Hayır \\
\hline
\end{tabular}

Kaynak: Tatar vd., 2011: 48 .

Türkiye'de sağlık hizmetleri finansmanında üç kaynak bulunmaktadır. $\mathrm{Bu}$ kaynaklardan birincisi, vergi gelirleriyle finanse edilen ve büyük oranda Sağlık Bakanlığı'na, Milli Savunma Bakanlığı'na, üniversite hastanelerine ve diğer kamu kuruluşlarına ve aktif devlet memurlarının sağlık hizmeti harcamalarına tahsis edilen genel devlet bütçesidir. İkincisi, SGK üyelerinden elde edilen sosyal güvenlik katkı primleridir. Üçüncüsü ise özel doktorlar ve kuruluşlara cepten ödeme ve gönüllü sağlık sigortası için 
ödenen primler ve ortak ödemeler şeklinde olan doğrudan cepten ödemelerdir (Atabey Ertürk, 2012: 154).

Türkiye'de kural olarak yaşayan tüm bireyler sağlık sisteminde evrensel kapsama ile kapsanmaktadır. Kapsam geneldir. Herkes sağlık sisteminden genel sağlık sigortasına sahip olmak koşuluyla ayrım yapılmaksızın sağlık hizmetlerinden faydalanmaktadırlar. Ancak uygulamada nüfusun yaklaşık \%7,6 'sının kapsam dışında kaldığı ve evrensel kapsamanın Almanya'da olduğu gibi Türkiye'de de gerçekleşmediği görülmektedir.

Sağlık için, evrensel kapsamada asıl olan, tüm vatandaşlar tarafından makul eşit erişimi sağlamak değil mutlak eşit erişimin sağlanmasıdır (Hsiao, 1995: 25).

Şekil: 2

\section{Toplam Sağlık Harcamalarında Finansmanın Ana Kaynakları}

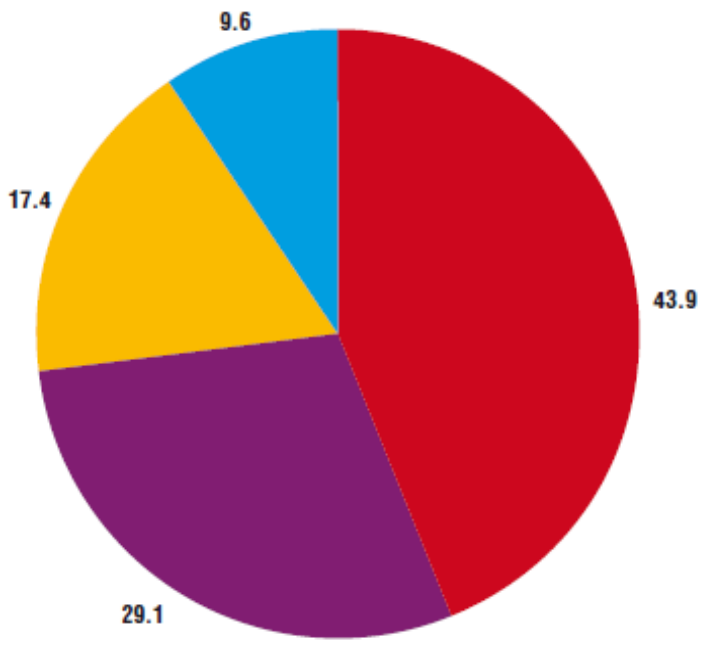

Sosyal Güvenlik Planları

Hükümet

Cepten Yapılan Ödemeler

Diğer Özel Ödemeler

Şekil 2'den de görüleceği üzere Türkiye'de toplam sağlık harcamalarının büyük bir kısmı Sosyal Güvenlik Planları ile sağlanmaktadır. daha sonra ikinci önemli payı ise \%29.1 oranı ile hükümetin genel vergi gelirlerinden ayırdığı payla finansmanını sağladığı izlenmektedir. 


\section{Sonuç}

Türkiye'de ve Almanya'da da tüm dünyada olduğu gibi özellikle son on beş yılda sağlık harcamalarının GSYİH'e oranı önemli ölçüde artmıştır. Çalışmada incelenen Türk ve Alman sağlık sistemlerinin her ikisinde de yönetimin çok başlı olması ortak bir sağlık politikası belirleyip bu politikayı gerçekleştirmeyi ve sürdürebilmeyi engellemektedir. Sağlık sistemlerinin planlanması ve finansmanında yetki alanlarının birleşmesinde ortaya çıkan bu zorluk da sağlık sisteminin bütünü açısından sorumluluğun belirsiz kalmasını ve sistemin kusurlarının kimler tarafından farkındalığının sağlanıp çözümünün üretileceği noktasında ciddi sorunlar oluşturmaktadır. Her iki sağlık sisteminde de sistemin farklı organları arasında uyum ve birliktelik sorunlarının ana kaynağı her bir organın ayrı önceliğinin bulunmasından oluşmaktadır.

Toplam sağlık harcamalarında kamusal kaynakların yüzdesi bakımından Almanya Avrupa ülkeleri arasında on sekizinci sırada yer alırken Türkiye'de on dokuzuncu sırada yer almaktadır. Ancak kamu kaynaklı sağlık harcamalar son onbeş yıl içerisinde ciddi boyutta azalmaktadır. Bunun en önemli sebebi de özel harcamalardaki artış ve vergi ile finanse edilen hizmetlerin yüzdesindeki azalmadır.

Almanya'da kural olarak yaşayan tüm bireyler sağlık sisteminde evrensel kapsama ile kapsanmaktadır. Kapsam geneldir. Herkes sağlık sisteminden yasal sağlık sigortasına sahip olmak koşuluyla ayrım yapılmaksızın sağlık hizmetlerinden faydalanmaktadırlar. Ancak uygulamada nüfusun yaklaşık \%11'inin kapsam dişında kaldığı ve evrensel kapsamanın bu ülkede gerçekleşmediği görülmektedir.

Türkiye'de kural olarak yaşayan tüm bireyler sağlık sisteminde evrensel kapsama ile kapsanmaktadır. Kapsam geneldir. Herkes sağlık sisteminden genel sağlık sigortasına sahip olmak koşuluyla ayrım yapılmaksızın sağlık hizmetlerinden faydalanmaktadırlar. Ancak uygulamada nüfusun yaklaşık \% 7,6 'sının kapsam dışında kaldığı ve evrensel kapsamanın Almanya'da olduğu gibi bu ülkede de gerçekleşmediği görülmektedir.

Özel sağlık sigorta sistemi ve zorunlu sosyal sigorta sistemini ağırlıkla uygulamayı seçen ülkelerde bu sistemlerin yapılarından dolayı vergilerle finansmanı sağlayan ülkelere göre işgücü piyasasındaki hareketliliği olumsuz yönde etkileyerek genel olarak ekonominin verimsizliğine neden olabilmektedir. İş değişikliği nedeniyle sağlik sigortasını kaybedecek olanlar daha verimli çalışabilecekleri işlerden vazgeçerek emek hareketsizliği sonucunda ekonomiyi olumsuz yönde etkileyebilmekte ve yine sigorta primlerinin işgücü maliyetlerini artırarak istihdamı ve küresel rekabeti olumsuz yönde etkilemesi de mümkün olabilmektedir.

Sağlık hizmetlerinin finansmanında yasal/zorunlu sağlık sigortasını benimseyen her iki ülkede de asıl sorun OECD'nin 2000 yılında yaptığı bir analizde ulaşılan sonucunda 
gösterdiği üzere bu finansman yönteminin vergilerle finansmana göre daha maliyetli bir sistem olmasından kaynaklanmaktadır.

Sağlık sistemlerinin gelişiminde önce ulusal sağlık sistemleri yaklaşımı güçlenmiş daha sonra sağlık sistemlerinde özelleştirme yaklaşımı güçlenmiştir. Bir kesim tarafından özel sektör eleştirilmekte ve özel sektörün kar odaklı hareket ettiğini ve dolayısı ile düşük karlı olarak gördükleri sağlık alanlarına yatırım yapmadıklarını savunmaktadırlar. Ancak özel sektörün artan katılımına yönelik yaklaşımlar da çeşitlidir. Şöyle ki; özel sektörün daha iyi organize olduğu ve mikro düzeyde daha etkin hizmet sunacağı mekanizmalar geliştirdiği savunulmaktadır. Günümüzde Almanya ve Türkiye'nin de içinde olduğu pek çok ülke, sağlık hizmetlerinin sunumunda özel sektörün optimal katkısının ne olacağı üzerinde tartışmaktadır. Sonuçta, ülke uygulamaları incelendiğinde devletlerin sağlık alanında halen tartışılmaz bir düzenleyici ve denetleyici rolü bulunduğu görülmektedir.

\section{Kaynaklar}

Altay, A. (2008), "Sağlık Hizmetlerinin Sunumunda Yeni Açılımlar ve Türkiye Açısından Değerlendirilmesi”, Sayıstay Dergisi, 64, 33-58.

Akdemir, T. \& B. Karakurt (2009), "Sağlık Hizmetlerinde Devletin Değişen Rolü ve Özel Sağlık Kurumlarının Düzenleyici Görevleri”, 24. Türkiye Maliye Sempozyumu, Antalya, 221260.

Atabey Ertürk, S. (2012), Sağllk Sistemleri ve Sağllk Politikası, Gazi Kitabevi, Ankara, Ekim.

Busse, R. \& M. Blümel (2014), “Germany Health System in Review”, Health Systems in Transition, 16(2), The European Observatory on Health Systems and Policies is a partnership, hosted by the WHO.

Hsiao, W.C. (1995), "A Framework for Assessing Health Financing Strategies and the Role of Health Insurance", in: An International Assessment of Health Care Financing Lessons for Developing Countries, eds. D.M. Dunlop \& Jo.M. Martins, The World Bank, Washington D.C.

Mossialos, E. \& M. Wenzi \& R. Osborn \& C. Anderson (2015), International Profiles of Health Care Systems 2014, January, The Commonwealth Fund.

Normand, C. \& S. Thomas (2009), "Health Care Financing and the Health System", in: Health Systems Policy, Finance and Organization, ed. G. Carrin, Gennova, 149-163.

OECD (2000), OECD Health Data 2000: A Comperative Analysis of 29 Countries, Paris, Organization for Economic Co-operation and Development.

Süzek, S. (1985), İşgüvenliği Hukuku, Birinci Baskı, Savaş Yayınları, Ankara.

Tatar, M. \& S. Mollahaliloğlu \& B. Şahin \& S. Aydın \& A. Maresso \& C. Hernández-Quevedo (2011), "Health Systems in Transation", Turkey Health System Review, Turkey, World Health Organization 2011, on behalf of the European Observatory on Health Systems and Policies.

WHO (2015), What is Universal Coverage, <http://www.who.int/health_financing/universal_coverage_definition/en/>, 23.09.2015. 
Ertürk Atabey, Selin \& M. Meriç (2016), "Sağlık Harcamaları ve Evrensel Kapsama Açısından Türk ve Alman Sağlık Sistemlerinin Karșılaștırmalı İncelenmesi”, Sosyoekonomi, Vol. 24(29), 113-131. 